\title{
未治療で経過した先天性後鼻孔閉鎖例
}

\author{
設楽 化一加納 有二

\section{A Case of Untreated Congenital Choanal Atresia}

\author{
Jin-ichi Shidara and Yuji Kano \\ (Teikyo University)
}

\begin{abstract}
A young girl, 5 years and 9 months of age, was referred to our hospital because of nasal obstruction, mouth breathing and coughing at night. At 6 years of age, reconstructive surgery for the treatment of bilateral choanal atresia was performed using a transnasal approach. Airway tubes were retained in each choanae for 4 months after the surgery. Reobstruction of both choanae was not recognized until two years after the surgery. Nasal obstruction and mouth breathing had improved, but mouth breathing sometimes occurred unconsciously. The patient was able to recognize strong smells, but could not identify what the smells were. It is generally agreed that bilateral choanal atresia in the newborn with dyspnea is an emergency situation. This patient evidently did not experience dyspnea and survived without surgery because she was able to breathe orally since newborn. Considering that the patient's problems, such as nasal obstruction and disturbances of the sense of smell had been prolonged, surgical treatment for bilateral choanal atresia was recommended as soon as possible. This paper comprises a discussion of clinical symptoms in a case of untreated congenital choanal atresia.
\end{abstract}

Key words : bilateral congenital choanal atresia, clinical symptoms, surgery and age of treatment

はじめに

先天性後鼻孔閉鎖症は 6000 人から 8000 人に 1 人の割合 で発生すると報告されて括り1)2，比較的稀な疾患であ る.

本症の発見や診断の時期は随伴する症状によって異な るが多くの場合, 乳児期に呼吸困難や哺乳障害で発見さ れることが多い，しかし小児の中には生下時より口呼吸 を行らことができるものがあるといわれ，幼児期あるい は成人になってから本症が発見されることも報告されて (る3) 6).

本症の臨床的な問題点としては, 早期の重篤な症状で ある呼吸困難や哺乳障害の他に, 幼児期まで治療が遅れ た場合には, 構音障害, 嗅覚障害, 身体・精神発達障害, 䀘や睡眠時無呼吸症候群などを呈することである.
今回われわれは，6歳まで未治療で経過した先天性後 鼻孔閉鎖症の 1 例を経験したのでこれらの臨床上の問題 点を考察して報告する.

\section{症例}

症例： 5 歳 9 力月，女児.

主訴：鼻閉，口呼吸，夜間の咳嗽発作.

現病歴扣よび既往歴 :

患児は1985年12月 6 日, 在胎36週, 生下時体重 2600 $\mathrm{g}$, 正常分婏にて出生した. 生下時に臍帯へルニアがあ り全身麻酔下に手術を施行された. 同病院にて先天性後 鼻孔閉鎖症と診断されたが，心奇形や外表奇形は認めら れなかった，後鼻孔閉鎖症に対し手術が必要であると言 われたが, 生下時より口呼吸が可能であり, 発育も問題 
なからたためそのまま放置されていた，5歳 9 力月時, 上記主訴のため手術治療を希望し1991年 9 月 5 日，当院 を受診した。

家族歷：特記すべきことなし.

初診時所見：

患児の身長は $113 \mathrm{~cm}$, 体重 $20 \mathrm{~kg}$ とやや小さく，口 呼吸が著しかった．前鼻鏡所見では鼻内に鼻汁が充満し， 綿棒を挿入すると途中で挿入できなかった。後鼻鏡で後 鼻孔に閉塞が認められた。咽頭所見では，扁桃の肥大や 硬口蓋の位置に異常を認めず, 軟口蓋も左右対称で挙上 運動も良好であった。喉頭所見にも異常を認めなかった。 術前の前鼻鏡所見を図 1 に示した.

検査打よび治療経過：

鼻・副鼻腔の単純レントゲン, CT 执よび MRIを施 行した。術前の鼻・副鼻腔のCT 拉よび MRIを図 2, $\mathrm{a} \sim \mathrm{c}$ に示した. 後鼻孔に一致して厚い粘膜様の閉鎖を 認めた。両者とも骨性の閉塞を示す所見はなく, 膜性に 閉鎖しているものと考学られた. 上顎洞には炎症所見を 認めなかったが，両側の篩骨洞に軽度の粘膜肥厚を認め た。胸部の理学的所見には異常なく，血圧は110/58 $\mathrm{mmHg}$ と正常範囲内であり, 頻脈等の心電図異常も認

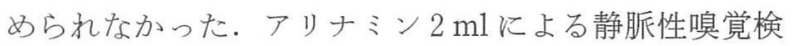
査を施行したが，アリナミン臭の自覚は得られなかった。

1991年11月 13 日, 当院に入院し，11月20日全身麻酔下 に後鼻孔開放術を施行した。患児が 6 歳と比較的大きく， 鼻内からの観察が容易であったため, 内視鏡下に後鼻孔 を開放した。後鼻孔は粘膜性の閉鎖であった。後鼻孔開 放後, 鼻内に内径 $6 \mathrm{~mm}$ の気管内挿管用マリンクロット チューブを挿入し，鼻腔の前後で結禁し固定した。同年 12月26日, 鼻漏が多く鼻内より異物臭を認めたため, 同 径のファイコンカテーテルに交換した.

1992年 3 月 10 日 (術後約 3 力月目), 鼻内のチューブを 抜去した，抜去後は鼻呼吸が可能となったが，無意識に 口呼吸をしていることも多いとの訴えがあった。1993年 3月23日に施行した鼻・副鼻腔 CT t図 2, d に示した. 後鼻孔は十分に開放されていた。1994年 8 月, 手術後 2 年 9 カ月を経過した現在，後鼻孔の再閉鎖は見られてい ない。

切除した閉鎖部の病理組織所見を図 3 に示した。閉鎖 した後鼻孔の粘膜は鼻腔側，咽頭側之もに多列線毛円柱 上皮で覆われた膜性線維性組織で，漿液腺，粘液腺を認 め慢性炊症を伴っていた。切除した組織のなかには骨や

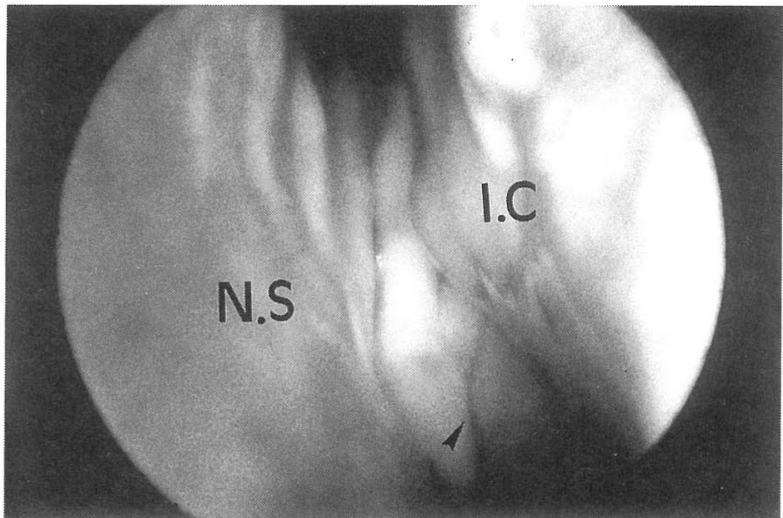

(a)

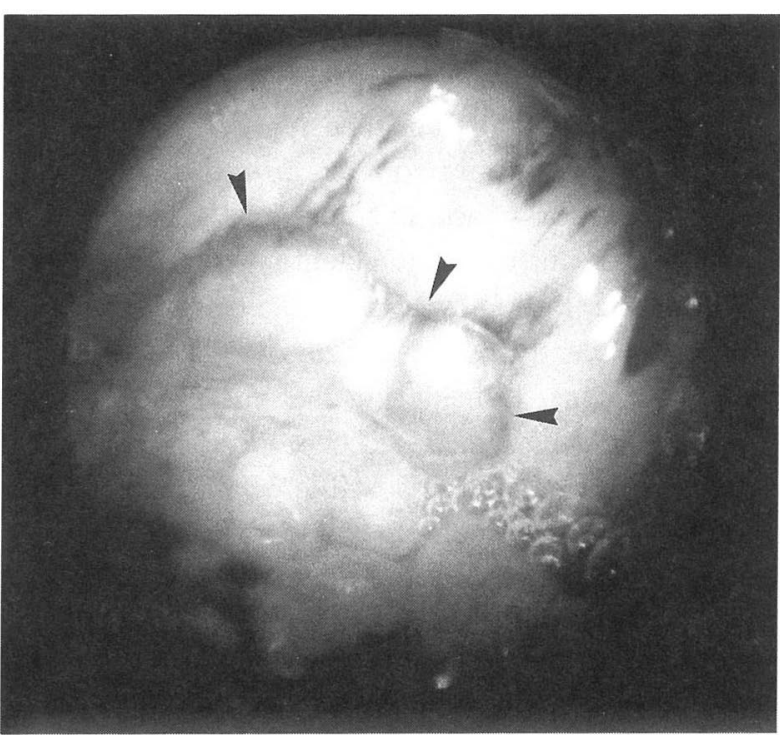

(b)

図 1 術前の前鼻鏡所見

$\mathrm{a}:$ 左前鼻鏡所見

b : 内視鏡下での後鼻孔所見 $($ 鼻腔より見た後鼻孔閉鎖 部)

I. C : 下鼻甲介 N.S : 鼻中隔 後鼻孔の閉鎖を認める $(\boldsymbol{A})$.

軟骨組織は認めなかった。術後 2 年経過後に嗅裂部の粘 膜を採取したが，採取した部の嗅裂部粘膜には嗅上皮や 嗅神経は確認できなかった。しかし術後からは嗅覚を訴 学るよらになってきて括り, 再度施行した静脈嗅覚検查 ではアリナミン静注から10秒後にアリナミン臭の自覚が 認められた。 


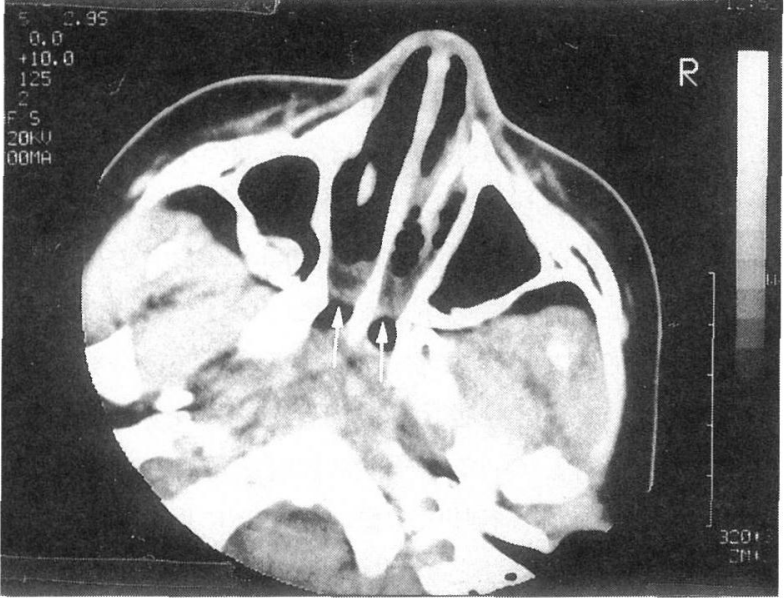

(a)

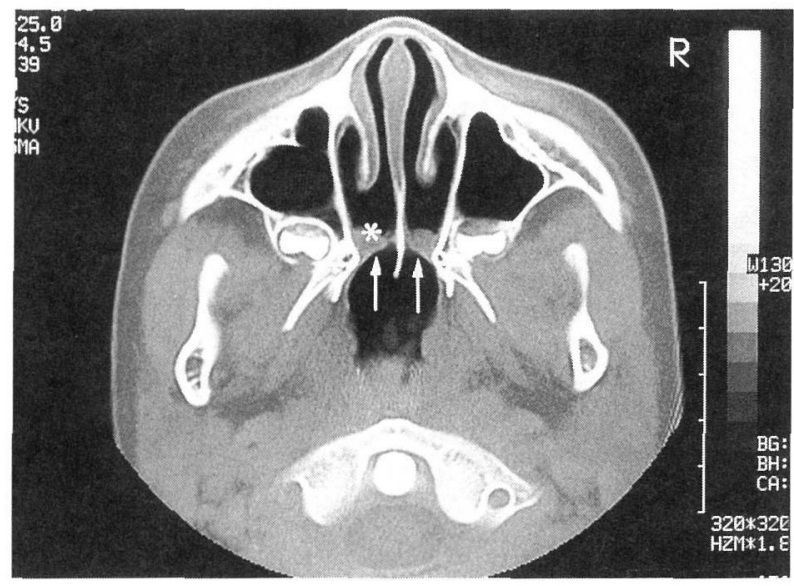

(b)

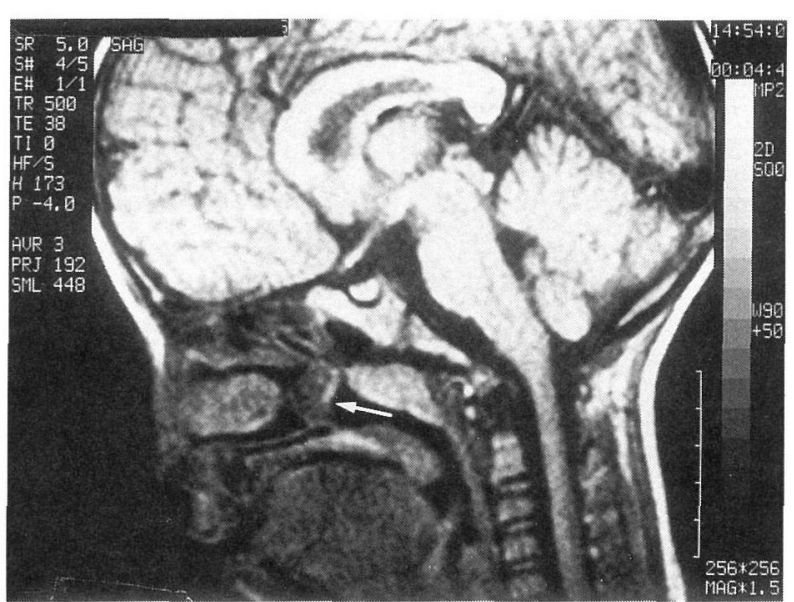

(c)

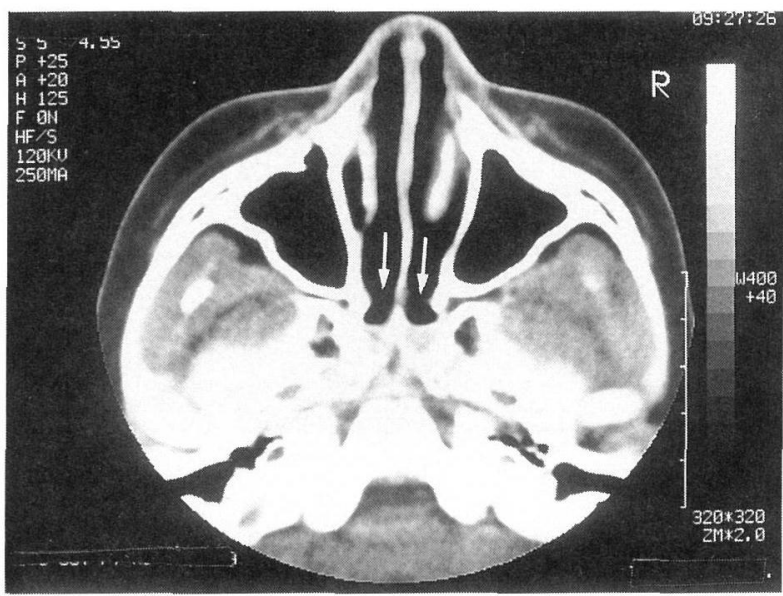

(d)

図 2 CT および MRI 所見

$\mathrm{a}$ : 術前の鼻・副鼻腔 CT

b : 術前の鼻・副鼻腔 CT, 骨強調像

c : 術前の頭部 MRI 正中矢状断像

後鼻孔部に一致して粘膜の閉鎖を認める。骨性の閉鎖は認められない，

a , b , c の矢印は膜性閉鎖部を示す。をたb図の*印は, 病理組織採取部を示す.

$\mathrm{d}$ ：術後の鼻・副鼻腔 CT

後鼻孔閉鎖部は広く開放されている。

矢印は開放された後鼻孔を示す。

\section{考察}

\section{1 ）後鼻孔閉鎖症の発見時期と臨床症状}

先天性後鼻孔閉鎖症のうち閉塞が一側性である場合に は, 副鼻腔炎として治療されている症例も西り, 疾患自 体の存在が見逃がされることがある。この場合には一側 の鼻閉や鼻漏を示すのみであり, 成人になってから本疾
患が発見されることも珍しくない。

後鼻孔の閉鎖が両側性の場合には，新生児の呼吸は鼻 呼吸に依存しているため呼吸障害によって死亡したり， 鼻呼吸障害に付随して起こる哺乳障害から，栄養障害や 誤燕に上る肺炎を繰り返す場合も岕る。したがって本症 候群が両側性である場合には乳幼児期の早期に手術治療 


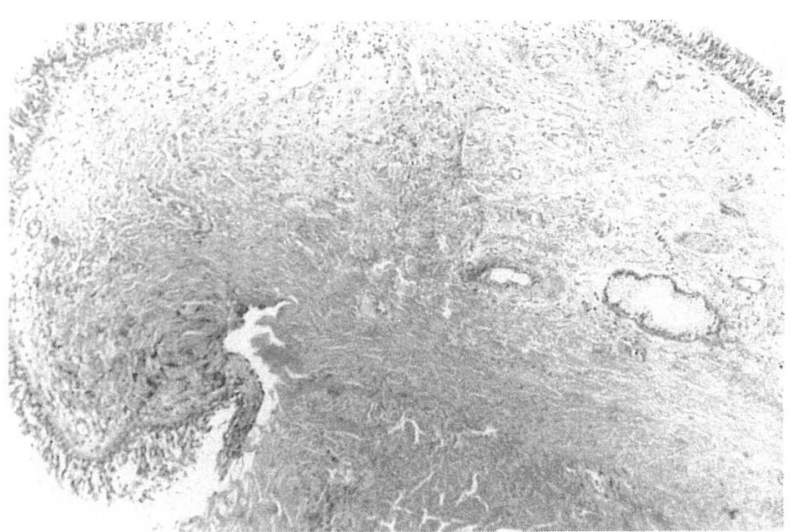

(a)

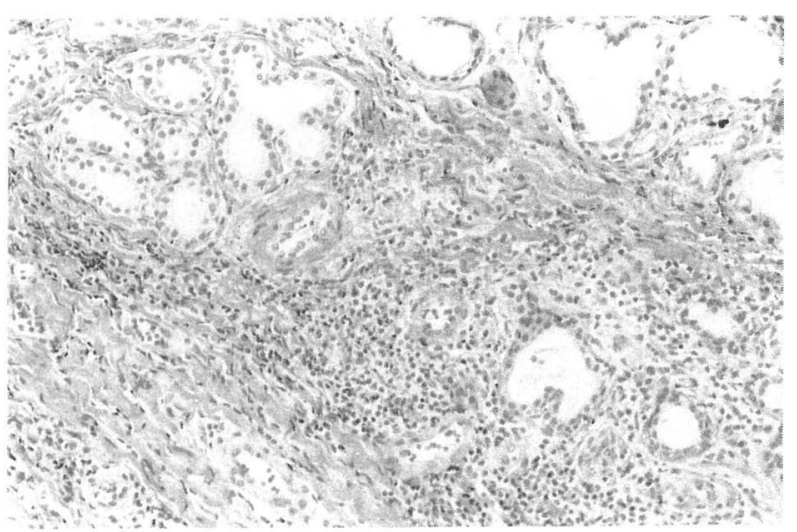

(b)

図 3 切除した後鼻孔閉鎖部粘膜の病理組織(図 2 bの*印の 部位より採取したもの)

$\mathrm{a}$ : 弱拡大 $(\mathrm{HE}$ 染色, $\times 40)$

切除した粘膜の表面を示す(鼻腔側)。多列線毛円柱上皮 で覆われた膜性線維性組織.

b : 強払大 $(\mathrm{HE}$ 染色, $\times 200)$

炎症性細胞浸潤を伴い, 漿液腺, 粘液腺を認める.

を受けることが多い。しかし両側性でありながら発見が 遅れたり，未治療で経過した症例も報告されている3) 6). 新生児の中には稀に生下時より口呼吸が行えるものもあ るとされて扣り，発見や治療が遅れる原因となることが 考光られる.

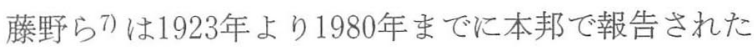
先天性両側性後鼻孔閉鎖症の29例の検討を行い, 10 歳以 上で発見された症例が16例であったと報告している。一 方, Evans $5^{8)}$ の報告では両側性後鼻孔閉鎖症28例の5 ち22例が 1 歳未満, 26 例が 3 歳未満で発見され，3 歳以 上はわずか 2 例で診断されている. 近年, CT や MRI
などによる診断技術の向上により本症が早期に発見され 治療されていることが多い9)101.

2 ）診断和よび治療の遅延例に打ける本疾患の問題点 先天性両側性後鼻孔閉鎖症は乳児期の早期に治療をら けることが多いため, 長期間未治療で放置された後鼻孔 閉鎖症の報告は少なく，また長期間の後鼻孔の閉鎖が患 者にどのよらな影響を与えるかについての報告はほとん どなされていない。本邦では洲崎ら 33 が22歳で発見され た患者について, 呼吸状態, 構音機能, 嗅覚などについ て詳細に報告している. 一般には呼吸障書, 構音障害, 嗅覚障害, 睡眠時無呼吸や鼾, これらに伴う身体あるい は精神発達の障害などが問題となると考学られる。

本症例では, 生下時から口呼吸が可能で, 発育が正常 であったため, 生下時の臍帯へルニアの手術時に両側性 後鼻孔閉鎖症と診断されたにもかかわらず，治療される ことなく 5 歳 9 カ月時まで放置されていた。

患児の呼吸様式は術前にはすべて口呼吸によるもので あり，鼾をかくこともたびたびあった。手術後 2 年を経 過し，鼻呼吸がでさるようになり，鼾の程度も軽減した。 しかし無意識のうちにロ呼吸をしていることも多いよう である。

構音機能では術前には閉鼻声があり鼻音 $(/ \mathrm{m} /, / \mathrm{n} /)$ の歪が強く, マ行が不明瞭でナ行はラ行に近い発音であ った。術後から徐々に鼻音の発音は改善しているが, 鼻 音の発音はいまだ不明瞭である。

嗅覚に関しては, 日常生活でも嗅覚の自覚が無く, 術 前のアリナミンテストでも反応が認められなかった。術 後には嗅覚は自覚するよらになったが, 強い嗅いに反応 するのみで, 何の嗅いであるか, あるいは軽微な嗅いに 関しては認知ができないよらである。

洲崎らうの報告した症例においてもナ行およびマ行の denasalization が認められ, 構音訓練 3 力月半後に会話 レベルが正常となったと報告している. 本症例も今後の 構音訓練により正常な発声が可能となると考光られる。 嗅覚について洲崎ら ${ }^{3)}$ の症例でも, 嗅いの存在はわかる が嗅いの認知がでさないとしている．Ritter ${ }^{11)}$ は喉頭摘 出患者と正常者との比較に执いて嗅上皮の廃用性萎縮は ないであらうと述べて扣り，その意味では後鼻孔の開放 により徐々に嗅覚の認知がなされる可能性があると思わ れる。一方で本疾患が無嗅脳症を合併することも知られ て沶り, 中枢性の嗅覚障害を合併している可能性も否定 できない、したがって本症の嗅覚の予後については今後 
の経過を見守る必要がある.

先天性両側性後鼻孔閉鎖症では, 嗅覚や音声の障害の 他にも，鼻閉塞による斯や睡眠時無呼吸症候群などが合 併する可能性も考兄られる. 構音機能や嗅覚機能が長期 間持続することは，患児の身体，精神的発達に大きな影 響を及ぼすものと考えられる。

3 ) 手術的療法と手術時期について

本疾患の根本的な治療としては, 手術的に後鼻孔を開 放することが必要であるが，手術の時期や方法について は, CHARGE association(目のコロボーマ, 心奇形, 後鼻孔閉鎖, 精神運動発達遅滞, 生殖器の低形成, 耳の

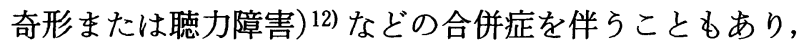
手術侵襲の問題から待機的に治療を行う必要がある場合 や，後鼻孔の再閉鎖の問題があり議論の分かれるところ である。

本疾患の手術的治療としては経鼻内法, 経中隔法, 抒 よび経口蓋法が報告されている．経口蓋法が確実な方法 であると考えられるが，乳幼児期には経鼻内法が推奨さ れているよらである1013).

手術時期に関しては Hobolth ら ${ }^{14)}$ は18力月頃が最適 であるとし, Winther ${ }^{15)}$ は 2 歳 5 カ月, Fearon ら ${ }^{16)}$ は 3 歳以内に手術を行うべきであるとしている. 患児の体 重を指標とした報告では, Maniglia ら ${ }^{17)} は$ 体重10ポン ド, 川城 ${ }^{18)}$ は体重 $5 \mathrm{~kg}$ を手術適応の指標として推奖し ている. 本症例では年齢が 6 歳で体重 $20 \mathrm{~kg}$ であり, 乳 幼児期の手術に比較し, 鼻内からの観察掞よび処置が容 易であったため経鼻内法の手術を施行した。

後鼻孔開放部へのチューブの留置に関しては, およそ 3 力月程度の留置が必要であるとの報告が多い，学童期 に手術を施行した場合, 鼻内に長期間チューブを留置す ることは, 患者に精神的な苦痛を与える可能性もあり, 家族や患者本人の理解が必要であると思われる. 本症例 では, 幼稚園に通園しながら約 4 カ月チューブを留置す ることができ，現在も再閉鎖なく良好に経過している。

\section{参考文献}

1) Ferguson $\mathrm{CF}$ : Congenital choanal atresia. Pediatric Otolaryngol vol II (ed by Ferguson CF and Kendig EL). pp 1002 1012, WB Saunders Co, Philadelphia, 1972.

2) Kazanjian VH : The treatment of congenital atresia of the choanae. Ann Otolaryngol $51: 704 \sim 711,1942$.

3 ) 洲崎春海, 川端五十鈴, 阿部雅子, 他: 両側先天性後鼻孔 閉鎖症の 1 例. 耳喉 $54: 85 \sim 91,1982$.

4 ) Candan S, Mizrak S, Karagoz M, et al. : Bilateral congenital choanal atresia at age 16 ; an interesting case. J Otolaryngol $20: 433 \sim 434,1991$.

5 ）松村裕二郎, 森満 保, 西田之昭 : 先天性後鼻孔閉鎖症の 1 例. 耳鼻 $12: 227 \sim 235,1966$.

6 ）西岡博之, 坂倉康夫, 鵜飼幸太郎, 他: 先天性後鼻孔閉鎖 症の 1 例. 耳鼻臨床 $73: 1581 \sim 1589,1980$.

7 ) 藤野明人, 岡本牧人, 鈴木 徹, 他: 先天性両側性後鼻孔 閉鎖症の 2 例. 耳喉 $54: 261 \sim 265,1982$.

8 ) Evans JNG and Maclachlan RF : Choanal atresia. J Laryngol $86: 903 \sim 929,1971$.

9 ）古賀慶次郎, 荒木照夫 : 後鼻孔閉鎖症. 小児外科 22 : 27 $\sim 31,1991$.

10）水田邦博,市村恵一：後鼻孔閉鎖症.JOHNS $8: 601 \sim 605$, 1992.

11) Ritter FN : Fate of olfaction after laryngectomy. Arch Otolaryngol $79: 169 \sim 171,1964$.

12) Pagon RA, Graham JM, Zonana J, et al : Coloboma, congenital heart disease, and choanal atresia with multiple anomalies ; CHARGE association. J Pediatr 99 : 223 227, 1981.

13）吉田 茂, 伊東一則, 島 哲也：先天性後鼻孔閉鎖の 3 例 と文献的考察. 口咽科 $5: 75 \sim 79,1993$.

14) Hobolth N, Buchmann G and Sandberg LE : Acta Paediatr Scand $56: 286,1967$.

15) Winther LK : Congenital choanal atresia. Arch Otolaryngol $104: 72 \sim 73,1973$.

16) Fearon $B$ and Dickson J : Bilateral choanal atresia in the newborn; plan of action. Laryngoscope 78 : 1487 1499, 1968.

17) Maniglia $\mathrm{AJ}$ and Goodwin $\mathrm{WJ}$ : Congenital choanal atresia. Otolaryngol Clin North Am $14: 167 \sim 173,1981$.

18）川城信子：後鼻孔閉鎖症. 周産期医学 $20: 833 \sim 836,1990$.

原稿受付: 平成 8 年 1 月 4 日 原稿採択: 平成 8 年 3 月 6 日 別刷請求先 : 設楽仁一

干173 東京都板橋区加賀2-11-1

帝京大学医学部耳鼻咽喉科学講座 